\title{
Globalization of Sundanese Food (West Java) through Cultural Translation
}

\author{
Tubagus Chaeru Nugraha \\ Sri Rijati Wardiani \\ Rosaria Mita Amalia \\ Davidescu Cristiana Victoria Marta
}

Universitas Padjadjaran

Indonesia

\begin{abstract}
One traditional food of Indonesian gastronomy already well-known in the world is 'Rendang Padang'. However, there are still many of Indonesian foods that match the taste of the world, including 'Soto' and 'Rawon'. One effort to introduce traditional food is through cultural translation. Therefore, the purpose of this study is to describe the globalization of Sundanese food (West Java) through cultural translation. We expect that it will contribute to create sustainable economic development based on traditional culinary business community in ASEAN. To achieve the purpose of this study, an eclectic approach is used, namely the incorporation of theories that fit the objectives of the study. There are three main steps in this study: First, the provision of selected data in the form of a corpus of Sundanese food names. Second, the data analysis is conducted using a method of cultural translation, because translation is a process of intercultural communication act (intercultural transformation). Third, the data is presented in the form of descriptive explanation. There are three findings of this study. First, there are strategies, methods, and techniques of Sundanese culinary translation in French language and Arabic language. Cultural translation techniques include pure lending of regional languages, use of generic terms, scientific Latin name, definition, and adaptation. Second, there are similarities and the differences between source language and target language. Third, it has been proven that the translation of Sundanese culinary names helps to introduce Sundanese cuisines globally through the development of human resources capacity in culinary business community, especially in the field of marketing and promotion.
\end{abstract}

Keywords: Cultural Translation, Globalization, Sundanese Food

\section{Introduction}

The development of community is an active process of community empowerment with sustainable learning based on principles of justice, participation, and cooperation. The process of community empowerment aims to raise the full participation of community so that the community ability and integration become independent. One type of community development is the development of community-based culinary tour. Tourism in developing countries is mostly seen as not bringing significant economic benefits, both for the countries and local society. This imbalance occurs because most of large scale tourism businesses are monopolized by great entrepreneurs. This culinary tourism business establishes some standards for every aspect of its activities (Purnamasari, 2011). The translation of Sundanese culinary variety is expected to help culinary business community in developing Sundanese (West Java) culinary tourism to the international world.

Translation is a science and art to transfer the text meaning of source language to target language. By the science of translation, a translator could decide the type of text, the knowledge field, the stylistic, and the purpose of translation, while using the art-skill of translation, the translator could decide the strategy, choose the method and the right technique based on the translation purposes. In the cultural context, translation can be defined as intercultural communication act or more than that as an intercultural transformation, because through translation the information, the feeling, the value or the ideology are transformed from one language to another.

Translation problem usually happens when translating cultural terminologies. The translation of cultural terminologies often becomes a problem if the target language does not have the same concept. For example, cultural translation for Sundanese culinary words that refer to rice like pare, beas, sangu, and timbelis (ar-ruzza) in Arabic language or "rice" in English, but both of the translations are not complete and clear enough. Because of it, the translation needs 
additional explanation, for example beas $\rightarrow$ نبات الرز(naba:tu'r-ruzzi).

Culture is characteristic association of a community or social group in social, spiritual, material, intellectual, and emotional areas. In other words, culture is a model of behavior and interaction of cognitive construction and understanding that are gained through socialization process. Then culture is multidimensional characteristic consisted of knowledge from a group of people starting from the spoken language, religion, cuisines, traditions, and habits, songs, and arts. The translation of cultural cuisines is an important thing that helps global culture diplomacy.

One of the cultural aspects is culinary culture that can be found all over the world. Language and food is universal things for human. Organic relation between food and words is not only a physiological accident, where the mouth is a means to eat and speak, but food also could only have meaning through verbalization. In every language, there are at least some words that are related to food and taste that show joy and dislike for a taste. Introduction to culinary culture of a nation or a tribe to other is a way to introduce their national culture. For that, the special or traditional food from a country or a region needs to be introduced to the world. This thing could be done by translating the understanding, the compositions, and also the benefits of a food.

The difference between linguistic and cultural backgrounds that exist between source language and target language is a problem that hard to be avoided. Searching and getting the right translation need a special ability. Besides, practical and theoretical knowledge, special knowledge and general knowledge are useful in understanding, translating, and utilizing target language. The difficulty to find the right translation seems so clear because of some elements that cannot be transferred or do not have right translation. These difficulties happen because of language factors that are called as linguistic untranslatability and the translation difficulty because of cultural untranslatability (Catford, 1965: 93-1-3)

In Sundanese culture, there are terminologies known as Sundanese fresh vegetables (lalaban), because Sundanese people love farming. One of the secrets why Sundanese are healthy is because fresh vegetables (lalaban) that consist of a lot of vitamin. Based on researches, plants or vegetables that are used in Sundanese cooking are kinds of alternative medicine planst for various diseases like high blood pressure, coronary heart disease, diabetes mellitus or diabetes, liver disease, asthma, and rheumatism.

This paper will discuss about the following problems:

1. What are the strategies and methods used in translating Sundanese cuisines (West Java)?

2. How is the translation technique for regional food especially for kinds of sambal(hot sauce) that accompany the fresh vegetables (lalaban)?

3. How are the impacts of Sundanese culinary translation on the development of the culinary business community?

\section{Methodology}

According to Baker (1998:26), there are many translation strategies for unknown words or expressions in target language, one of them is translation by lending word. Another strategy is to preserve the original terminology with some explanations. The translator could also complete the original terminology with illustration.

This research method is a Sundanese culinary text analysis using Sundanese language as source language (ScL), with Arabic and French languages as target language (TgL). The approach used is qualitative descriptive by content analysis study. Qualitative descriptive means that this research has purposes to make description and explanation after analyzing the data from source language $(\mathrm{ScL})$ and its translation in target language $(\mathrm{TgL})$. Sundanese language data gathered were classified into elements included in category of cultural words. Then the data were categorized based on translation strategy used and analyzed on how the cultural words are translated in to target language. The analysis resultswere presented into tables and discussed about the translator chosen strategy including the cultural terminology used by the translator.

\section{Results and Discussion}

3.1 The Use of Region Name in Cuisines 
Some traditional food names of West Java are based on the region name, for example in Table 1, there are some names of Sundanese traditional food.

Table 1.Sundanese Traditional Food

\begin{tabular}{|c|l|l|}
\hline No & Regional Food Name & Region on food's name \\
\hline 1. & PeyeumBandung & Bandungfermented cassava \\
\hline 2. & $\begin{array}{l}\text { TahuSumedang } \\
\text { UbiCilembu }\end{array}$ & $\begin{array}{l}\text { Sumedang deep-fried tofu } \\
\text { Cilembu sweet potato }\end{array}$ \\
\hline 3. & PindangGunungCiamis & Ciamis salted and stewed fish \\
\hline 4. & DodolGarut & $\begin{array}{l}\text { Garutsweets made from sticky rice powder and palm sugar with coconut } \\
\text { milk and sesame seed }\end{array}$ \\
\hline 5. & $\begin{array}{l}\text { Tape KetanKuningan } \\
\text { TahuLamping }\end{array}$ & $\begin{array}{l}\text { Kuningan Sticky rice Tapai } \\
\text { Original tofu from Kuningan, the name of 'Lamping' refers to the } \\
\text { location where this cuisine is created. }\end{array}$ \\
\hline
\end{tabular}

These are the cultural terminologies found in Sundanese culinary text.

\subsubsection{Natural Lending Technique}

Table 1.1. Natural Lending Technique

\begin{tabular}{|c|c|c|c|}
\hline \multirow[t]{2}{*}{ No } & \multicolumn{2}{|c|}{ Cultural Terminology } & \multirow[t]{2}{*}{ Translation Technique } \\
\hline & ScL & TgL & \\
\hline 1 & DodolGarut & دودول غاروت & Natural lending \\
\hline 2 & Peyeum Bandung & بييام باندونج & Natural lending \\
\hline 3 & Karedok & كاريدوك & Natural lending \\
\hline 4 & Tutugoncom & توتوغ اونثوم & Natural lending \\
\hline 5 & Ulukuteukleunca & اولوكوتيق ليونجا & Natural lending \\
\hline
\end{tabular}

Natural lending technique was done by preserving the source language in translation text $(\mathrm{TgL})$. But the lending was followed by pronunciation adjustment in TgL Bandung $\rightarrow$ / باندونج/Bandunj/. The finding results above known as $\mathrm{TgL}$, it is only the pronunciation that customized with the $\mathrm{TgL}$. The words is number 3 until 5 were naturally borrowed, but the concept of ScL is not well-known yet in $\mathrm{TgL}$.

\subsubsection{Reduction Technique}

Table 1.2. Reduction Technique

\begin{tabular}{|l|c|c|l|}
\hline \multirow{2}{*}{ No } & \multicolumn{2}{|c|}{ Cultural Terminology } & \multirow{2}{*}{ Translation Technique } \\
\cline { 2 - 3 } & ScL & TgL & \\
\hline 1 & cita rasa masakanSunda & reduction \\
\hline
\end{tabular}

The phrase cita rasa masakanSundais translated to طعم سوندا using reduction technique. This technique is done by removing some parts without causing meaning distortion. The phrase cita rasa is removed because the meaning id already represented by saying / طعم سوندا / "masakanSunda”only.

\subsubsection{Adaptation Technique}

Table 1.3.Adaptation Technique

\begin{tabular}{|c|l|r|l|}
\hline \multirow{2}{*}{ No } & \multicolumn{2}{|c|}{ Cultural Terminology } & \multirow{2}{*}{ Translation Technique } \\
\cline { 2 - 3 } & \multicolumn{1}{|c|}{ ScL } & TgL & \\
\hline 1 & gurih & adaptation \\
\hline 2 & perpaduanbumbunya & الذيذ من ماء مالح & adaptation \\
\hline 3 & sayuranmentah & الخضار النيئة & \\
\hline
\end{tabular}

This technique is known as cultural adaptation. It is done by replacing the cultural terminology of Sundanese language with the cultural terminology that is well-known in Arabic language.

\subsection{Translation for Fresh Vegetables Terminologies}

Table 2containes names of fresh vegetables (lalaban) which have the right translation in their target languages. The following vegetables could be fully understood by the French and Arabic languages. 
Table 2. Sundanese Lalaban

\begin{tabular}{|l|r|l|l|}
\hline \multicolumn{1}{|c|}{ Sundanese } & Arabic & \multicolumn{1}{c|}{ English } & \multicolumn{1}{c|}{ French } \\
\hline Bonteng & خيار & Cucumber & Concombre \\
\hline Engkol & ملفوف البابايا & Cabbage & Chou \\
\hline Daungedang & Pajaya leaf & Feuille de papaya \\
\hline Saladahcai & Watercress & Cresson \\
\hline Buncis & Bean & Haricots verts \\
\hline
\end{tabular}

\subsubsection{Pure Lending Technique}

Table 2.1. Pure Lending Technique

\begin{tabular}{|c|c|c|c|}
\hline \multirow[t]{2}{*}{ No } & \multicolumn{2}{|c|}{ Cultural Terminology } & \multirow[t]{2}{*}{ Translation Technique } \\
\hline & ScL & TgL & \\
\hline 1 & Bonteng & خيار & Pure lending \\
\hline 2 & Engkol & ملفوف & Pure lending \\
\hline 3 & Daungedang & ورقة البابايا & Pure lending \\
\hline 4 & Lalapan & حضروات طارجة & Pure lending \\
\hline 5 & Saladahcai & البقلة & Pure lending \\
\hline
\end{tabular}

The pure lending technique was done by preserving the ScL exactly the same into the $\operatorname{TgL}$ text. Because the terminologies translated were cultural terminologies, there are two possibilities, (1) cultural concept in ScL is wellknown and can be found in $\mathrm{TgL}$ text, (2) cultural concept in $\mathrm{ScL}$ is unknown in TgL, so additional explanation is needed.

For cases number 1-5, the cultural concepts are well-known and it is enough to translate it the way it is or it doesnot need any modification.

\subsubsection{Use of the Latin Scientific Name}

Table 2.2.SundaneseLalaban in Latin Terminology

\begin{tabular}{|l|l|l|l|}
\hline \multicolumn{1}{|c|}{ Sundanese } & \multicolumn{1}{|c|}{ Indonesian } & \multicolumn{1}{c|}{ Latin Scientific } & Picture \\
\hline Genjer & Genjer & limnocharisflava & \\
\hline Daunhitut & Daunkentut & paederiefetide & \\
\hline Kembangtikotok & Kenikir & cosmos caudatus & \\
\hline
\end{tabular}

This technique is used because French or Arabian people might not know the plants. The complete list of fresh vegetable (lalaban) names can be found in Latin terminology. But we need to consider that Latin namesare only known in limited circles, especially those who deal with botanical science. Pictures wereadded to help understandingmore appropriately,even if the kind of vegetables might be unknown in target cultures.

\subsubsection{Use of Sundanese Language with Pictures}

The use of Sundanese language with pictures is similar to the use of Latin scientific name with picture. These two techniques can be choses for each own reason. People tend to refuse the use of scientific names in daily life,because the terminologies in Sundanese are much easier to remember and shorter. For examples, the word jengkolin Sundanese is used instead of Archidendronpauciflorumin Latin, and the word katukin Sundanese is used instead of Sauropusandrogynus in Latin. 


\section{Table 2.3.Sundanese Lalaban with Pictures}

\begin{tabular}{|c|c|c|c|}
\hline Sundanese & Picture & Sundanese & Picture \\
\hline Jengkol & & Katuk & $x=32+4$ \\
\hline
\end{tabular}

\subsubsection{Use of Generic Terminology}

The technique of using generic terminology is equipped by explanation or information. The sample is the term Jaat. Look at Table 2.4 for the use of Sundanese lalaban generic term.

Table 2.4. Generic Terminology of SundaneseLalaban

\begin{tabular}{|l|l|l|}
\hline 1 & Jaat & a kind of leaf \\
\hline 2 & Jaat & a leaf type that is commonly found in.... (location) \\
\hline 3 & Jaat & a leaf type that is shaped ... (shape) \\
\hline 4 & Jaat & a leaf type that has texture like... (texture) \\
\hline 5 & Jaat & a leaf type that tastes like... (taste) \\
\hline
\end{tabular}

If the purpose is to give information that jaat is (1) a leaf and not the other (such as fruit), then the explanation will stop there. However, if it is not enough, then we can add other information and explanation like: (2) location, (3) shape, (4) texture, and (5) taste. This comparison technique is mostly used in daily life when we face the situation where we have to explain something to other.

\subsection{Translation of Sundanese Sambal Variants}

In French culture, the liquid that complete the food is called juice or sauce. Juice is liquid, and sauce is more viscous. It is different with sambal which is not a liquid called sauce. Allof sauces with chili as main ingredient is called as sauce de piment. In Indonesian context, chili sauce is defined as sauce whose main ingredient is mashed chilies, and we cannot see its real shape (such as packing sauce). It is important to say that sambal is sauce with chili as the main ingredient and the shape of chili is still known, especially when it is made manually. There are many variants of sambal in Sundanese culinary culture. Because of that, it will be classified into four types. First type is sambal with additional raw ingredient that explains the origin of sambal variants. See Table 3.1 for Sundanese sambal variants.

Table 3.1.SundaneseSambalwith Raw Ingredients

\begin{tabular}{|l|l|l|}
\hline 1 & sambalkemiri & sambal that is added with candlenut \\
\hline 2 & sambaltomat & sambal that is added with tomato \\
\hline 3 & sambalkencur & sambal that is added with kaempferiagalanga \\
\hline
\end{tabular}

Based on table 3.1, we could see that the concept of sambal can be understood well by French people. From here, we can conclude that translation problem is in the material or ingredient added into sambal. It means that we face the same problem while translating the vegetable's name. There is a word that can be translated directly such as tomato. On the other hand, we need to use other technique as written before, such as candlenut and kaempferia galangal.

Secondtype is sambal with additional processed ingredients

Table 3.2.SundaneseSambal with ProcessedIngredients

\begin{tabular}{|c|l|l|}
\hline 1 & Sambalterasi & $\begin{array}{l}\text { Sambal that uses terasi, a kind of small shrimp paste that is fermented and } \\
\text { used as sambal flavor }\end{array}$ \\
\hline 2 & Sambaloncom & Sambal that uses oncom, a kind of beans given a kind of fungus. \\
\hline
\end{tabular}

Terasi is a kind of small shrimp paste that is fermented and is used as sambal flavor (C'estunesorte de patéfermenté de petites crevettes). In this case, we need explanation because terasi is unknown in French. At least, the main ingredient is known by French. Oncom is also unknown in French and is translated as peanuts given a kind of fungus (c'estunesorte de cacahuettesfermentées de fungus).

Those kinds of sambal complements are not known in French. Therefore, sambal can be explained by giving a short detail of basic ingredient and the way to process it. The common information that, French people want to know about a food is related to health problem and hygiene. The doubt mostly comes when a new food is introduced while the food seems strange for them.

Fourth type is sambal with explanation of the making process 
Table 3.3.SundaneseSambal Variant with Process Explanation

\begin{tabular}{|c|l|l|}
\hline 1 & Sambalgoang & Raw sambal (De la sauce de pimentfraiche) \\
\hline 2 & Sambalbajak & $\begin{array}{l}\text { Cooked sambal (la sauce de pimentcuitemélangé aux tomates et } \\
\text { oignons })\end{array}$ \\
\hline
\end{tabular}

Fourth type is sambal using literal translation technique

Table 3.4. Literal Translation of SundaneseSambal

\begin{tabular}{|c|c|c|c|}
\hline \multirow[t]{2}{*}{ No } & \multicolumn{2}{|c|}{ Cultural Terminology } & \multirow[t]{2}{*}{ Translation Technique } \\
\hline & ScL & TgL & \\
\hline 1 & SambalTerasi & الصلصة الفلفل الحار - - & literal \\
\hline 2 & SambalOncom & الفلفل الحار فطيرة جوز البقان & literal \\
\hline 3 & SambalMuncang & معجونالفلفل الحار & literal \\
\hline
\end{tabular}

Those are some samples in introducing cultural context, where a lot of considerations are needed, whether from the meaning aspect, the culture, the receiver, and the efficiency of explanation. Based on the explanation presented, kinds of cultural translation technique can be used in order to deliver the purpose of cultural aspect in the right target and also the right terminology.

\subsection{The Impacts of Sundanese Culinary Translation in the Development of Culinary Business Community}

In the development of tourism especially culinary tourism, the aspect of local community empowerment has become one of the agreements and commitments that must be realized in order to support the sustainable tourism development, which emphasizes the realization of nature resources quality, tourism experience quality, and life quality of the local community (Susanto, 2010). Related to improving the local society quality, the development of culinary business community is really important in developing culinary tourism. Therefore, the increasing of culinary human resources capacity is needed, in particular marketing area and Sundanese culinary promotion in order to make them able to translate various culinary into foreign languages.

Questionnaire results were gained from Sundanese culinary festival event with foreign students as the respondents. Sorts of Sundanese food and the ingredients were translated to foreign languages (English, Arabic, French). There are several important things from the questionnaire results:

1) Foreign students came from Arabic countries (Afghanistan, Iran, Bangladesh, Sudan, and Nigeria) and Asia (India, Vietnam, Thailand, Korea, China, and Japan).

2) $57 \%$ of respondents had seen Sundanese cuisines and ingredients around their residences or dormitories (restaurants, rice stalls, and supermarkets).

3) 54\% of foreign students had ever tasted the Sundanese cuisines and thought that the taste was delicious.

4) The favorite Sundanese cuisines for them are Soto Bandung (49\%) and Empal Gentong Cirebon (37\%).

5) The reasons why the respondents chose Soto Bandung and Empal Gentong Cirebon among others were the slices of tender meat and the complements such as tahu(tofu), oncom, lalapan (fresh vegetables), and sambal.

\section{Conclusion}

Based on the discussion, there are seven translation techniques found for Sundanese word of lalaban, they are: (1) natural lending technique, (2) addition region name, (3) reduction technique, (4) adaptation technique, (5) pure lending technique, (6) use of the latin scientific name (7) use of generic terminology by explaining the variant, shape, texture, and taste. As for Sundanese word of sambal, there are four translation techniques including: (1) adding raw ingredients, (2) adding processed ingredients, (3) explaining the making process, and (4) using literal translation technique.

Based on the result of questionnaire discussion at the Sundanese culinary festival, the existence of Sundanese culinary translation in foreign language helps respondents in deciding to taste the Sundanese cuisines. In the end, the respondents could know and even enjoyed the Sundanese cuisines. Those things prove that Sundanese culinary translation help the cuisines to be known globally.

\section{References}

Amalia, Rosaria Mita. (2017). Cultural Translation of Traditional Food from West-Java: A Media to Promote the Traditional Cuisine to the World. Prooceeding International Seminar Language Maintenance and Shift (Lamas 7) : The Vitality of Local Languages in Global Community: p.577-581

(http://eprints.undip.ac.id/57575/1/Prosiding_Lamas_7_unscure_Rosaria_Mita_Amalia.pdf) 
Baker, Mona.(1998). Rouledge Encyclopedia of translation Studies.London :Routledge

Catford, J.C (1965) A linguistic Theory of Translation, London : Oxford Univ. Press.

Fahrudin, A. (2011). Pemberdayaanpartisipasidanpenguatankapasitasmasyarakat. Bandung: Humaniora.

Mahsun, M. S. (2005). Metodepenelitianbahasa: tahapanstrategi, metodedantekniknya. PT RajaGrafindoPersada.

Nugraha, TC. (2008). Dasar-DasarPenerjemahanBahasa Arab: TeoridanPraktek. Bandung: AlqaprintJatinangor.

Nugraha, TC \&Amalia. (2017). Revitalization Of Sundanese'sNgalogat: Literacy In Education. Paper presented at The $1^{\text {st }}$ International Conference on Language, Literature and Teaching, IcoLLit. UMS, April 4-5.

Nurmalasari, Y. (2013). AnalisisPengelolaan Wilayah PesisirBerbasisMasyarakat. Stmikim.Ac. Id/userfiles/jurnal\% 20yessi.Pdf.

Philip, Bromely\& Tan Kim. (2006). Metacognitive Strategy Instruction (MSI) for Reading in E-Bangi Journal od Social Sciences and Humanities Vol.1, No.1 (Julai-Disember 2006) 1-22.

Purnamasari, A. M. (2011). PengembanganMasyarakatuntukPariwisata di KampungWisataToddabojoProvinsi Sulawesi Selatan. Journal of Regional and City Planning, 22(1), 49-64.

Suriawiria, Unus. (1987). Lalab: DalamBudayadanKehidupanMasyarakatSunda. Bandung: Granesia.

Susanto, D. (2010). Strategipeningkatankapasitas modal sosialdankualitassumberdayamanusiapendampingpengembanganmasyarakat. JurnalKomunikasi Pembangunan, 8(1).

https://id.wikipedia.org/wiki/Pengembangan_masyarakat. Accessed on May $15^{\text {th }} 2018$ http://journal.ipb.ac.id/index.php/jurnalkmp/article/view/5696. Accessed on May $20^{\text {th }} 2018$

http://www.disparbud.jabarprov.go.id/applications/frontend/index.php. Accessed on May $20^{\text {th }} 2018$ 